\title{
Synthesis and Study Antimicrobial Activities of Some Novel Tetrazole Derivatives
}

\author{
Maher I. Nessim ${ }^{1 *}$, Safaa I. Elewa ${ }^{2}$, Manal G. Mohamed ${ }^{1}$ \\ ${ }^{1}$ Egyptian Petroleum Research Institute, Cairo, Egypt. \\ ${ }^{2}$ Faculty of Women for Arts, Science and Education, Ain Shams University, Cairo, \\ Egypt.
}

\begin{abstract}
GOUR (2-phenol derivatives) were coupled with $1 H$-tetrazole-5-diazonium chloride to synthesize four new compounds namely 4-((1H-tetrazol-5-yl)diazenyl)-2-alkylylphenol $\left(\mathrm{T}_{\mathrm{a}-\mathrm{d})}\right.$. These prepared Azophenols reacted with two 4-alkoxy acids (8 and 10) to form two new series of 4-((1H-tetrazol-5-yl) diazenyl)-2-(alkyl)-phenyl-4-(octyloxy) benzoates $\mathrm{T}_{8 \mathrm{a}-\mathrm{d}}$ and 4-((1H-tetrazol-5-yl)diazenyl)-2-(alkyl)-phenyl-4-(decyloxy) benzoates $\mathrm{T}_{10 \mathrm{a}-\mathrm{d}}$ respectively. The structures of the twelve synthesized compounds were confirmed using the conventional tools of analysis, Elemental Analysis, FT-IR and ${ }^{1} \mathrm{H}-\mathrm{NMR}$ spectroscopy. The biological activity of the prepared compounds as anti-fungi and anti-bacteria was studied. Most of the prepared compounds possessed good antimicrobial action for Gram-positive and Gram-negative bacteria, whereas they gave no action on Aspergillus fumigatus or Candida albicans.
\end{abstract}

Keywords: Tetrazoles, Diazotization, Phenols, ${ }^{1} \mathrm{H}-\mathrm{NMR}$, Biological activity.

\section{Introduction}

Lately, research on active nitrogen-rich substances has received considerable attention for several reasons. First, their high positive enthalpies may release a large amount of heat on combustion as dinitrogen $\left(\mathrm{N}_{2}\right)$ is one of the major products [1]. Second, the formed nitrogen molecule may achieve a high specific impulse without undesirable smoke or soot. Third, the nitrogen molecule is an environmentally friendly final product. Tetrazoles, with their heterocyclic ring structure, fall within this class of highnitrogen compounds [2].

In fact, tetrazole is a class of synthetic five membered organic heterocyclic compounds containing four nitrogen atoms and one carbon atom and one hydrogen atom (Fig. 1). The simplest is $1 H$-tetrazole itself $\mathrm{CH}_{2} \mathrm{~N}_{4}$. It is white to pale yellow crystalline solid with weak characteristic odor, soluble in water and alcohol. It is acidic in nature due to presence of four nitrogen atoms. Numbering of tetrazoles were well known $[3,4]$. Tetrazoles are usually explosives. They are unknown in nature. They are used as gas generating agent for air bags. Tetrazoles undergo electrophilic as well as nucleophilic substitution [5].

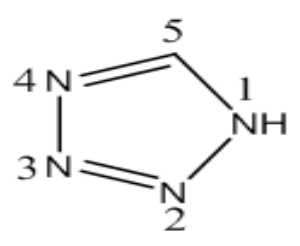

Fig. 1. $1 \mathrm{H}$-tetrazole

Due to the higher nitrogen content among the organic substances and the large positive enthalpies of formation, aminotetrazoles are prospective materials to be used, as blowing agents, solid propellants, and other combustible and thermally decomposing systems [6-10]. The number of publications devoted to the study of Tetrazoles increases each year. Significant advances have been made in their use in medicine $[11,12]$ and biology [13].

They are considered as bioisosteres of cis amides and carboxylic acids in medicinal chemistry with higher liphophilicity [14]. Although tetrazoles and their derivatives rarely occur in nature [15] the clear majority show biological activity [16]. Among them, 5-aminotetrazoles (Fig. 1) show anti-allergic and anti-asthmatic [17] 
antiviral and anti-inflammatory [18] antineoplastic [19] and cognition disorder activities [20]. Related compounds such as 30-(5-amino-1,2,3,4-tetrazol1-yl)-30- deoxy-thymidines and its derivatives were developed as anti-HIV drugs (Fig. 2) by Bayer [21].

Since Azo group is considered as a biological active group [22], we prepared in our work different azo tetrazole derivatives and they have been tested for their antimicrobial activity.
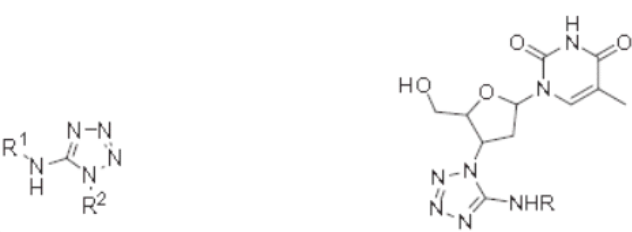

5-Aminotetrazoles

Anti-HIV drug

Fig. 2. Structure of 5-aminotetrazoles and related compounds

\section{Experimental}

Materials and chemicals

5-Aminotetrazole and 2-alkyl phenols, potassium hydroxide, sodium nitrite, hydrochloric acid, alkyl halides and ethyl-4-hydroxybenzoate purchased from (Sigma-Aldrich). Methylene chloride, ethanol, DCC and DMAP purchased from (Fluka). All chemicals were of analytical grade and used without further purification.

\section{Preparation of compounds Ta-d}

\section{Preparation of Diazotetrazole (T)}

5 grams of 5-aminotetrazole were dissolved in 30 $\mathrm{mL}$. of water containing $6 \mathrm{~mL}$. of $25 \%$ sodium hydroxide solution. To this solution 3.4 grams of sodium nitrite and 170 grams of crushed ice were added while the reaction flask was cooled with a salt-ice bath. Slowly from dropping funnel $16 \mathrm{~mL}$. of $30 \%$ cold hydrochloric acid was added at $0{ }^{\circ} \mathrm{C}$. By the end of the diazotization the color of the solution became greenish. Diazotetrazole is very sensitive as even solution with greater concentration than $6-7 \%$ at $0^{\circ} \mathrm{C}$ decomposed explosively [23].

Coupling with Phenol derivatives ( $a-d)$ The prepared diazonium chloride was added to an equimolar amount of alkaline solutions of compounds (a-d) at $0{ }^{\circ} \mathrm{C}$. The resulting precipitate was acidified and crystallized from absolute ethanol to yield compounds $\mathrm{T}_{\mathrm{a}-\mathrm{d}}$.

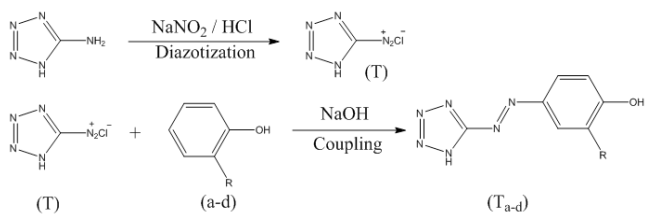

\begin{tabular}{|c|c|c|}
\hline $\begin{array}{l}\text { Comp } \\
\text { ound }\end{array}$ & $\mathbf{R}$ & Name \\
\hline $\mathrm{Ta}$ & $\mathrm{H}$ & $\begin{array}{l}\text { 4-((1H-tetrazol-5-yl)diazenyl }) \\
\text { phenol. }\end{array}$ \\
\hline $\mathrm{Tb}$ & $\mathrm{Me}$ & $\begin{array}{l}\text { 4-((1H-tetrazol-5-yl)diazenyl)- } \\
\text { 2-methylphenol. }\end{array}$ \\
\hline $\mathrm{Tc}$ & $\mathrm{C}_{2} \mathrm{H}_{5}$ & $\begin{array}{l}\text { 4-((1H-tetrazol-5-yl)diazenyl)- } \\
\text { 2-ethylphenol. }\end{array}$ \\
\hline $\mathrm{Td}$ & $\begin{array}{l}\text { Tert- } \\
\text { butyl }\end{array}$ & $\begin{array}{l}\text { 4-((1H-tetrazol-5-yl)diazenyl)- } \\
\text { 2-(tert-butyl)phenol. }\end{array}$ \\
\hline
\end{tabular}

Preparation of Compounds $T_{8 a-d}$ and $T_{10 a-d}$ 10

Preparation of 4-(alkoxy) benzoic acids 8 and

The 1-bromo alkane $(0.030 \mathrm{~mol}$.) was added dropwise to a stirred solution of ethyl -4-hydroxy benzoate $(0.030 \mathrm{~mol}$. $)$ in $50 \mathrm{~mL}$ ethanolic potassium hydroxide $(0.036 \mathrm{~mol}$.). Stirring was continued for two hours at $60^{\circ} \mathrm{C}$. Then the reaction mixture was left overnight at room temperature. The product obtained is hydrolyzed by adding potassium hydroxide $(0.030 \mathrm{~mol}$.) and refluxed for three hours. The hydrolyzed product was then cooled and acidified with dilute hydrochloric acid. The resulting alkoxy acids were crystallized from glacial acetic acid and exhibited phase transition temperatures agreed with those reported in the literature [24].

\section{Esterification}

Equimolar amount of both $\left(\mathrm{T}_{\mathrm{a}-\mathrm{d}}\right)$ and $(8,10)$, (0.01 mol.) were dissolved in $50 \mathrm{ml}$ methylene chloride. Dicyclohexyl carbodiimide (DCC, 0.011 mol.) and 4-dimethylamino pyridine, (DMAP as catalyst) were added to the solution mixture with stirring overnight at room temperature. The solution was filtered off and vaporized using rotary evaporator. The residue was crystallized from absolute ethanol to give $\left(\mathrm{T}_{8 \mathrm{a}-\mathrm{d}}\right.$ and $\left.\mathrm{T}_{10 \mathrm{a}-\mathrm{d}}\right)$ [25]. 

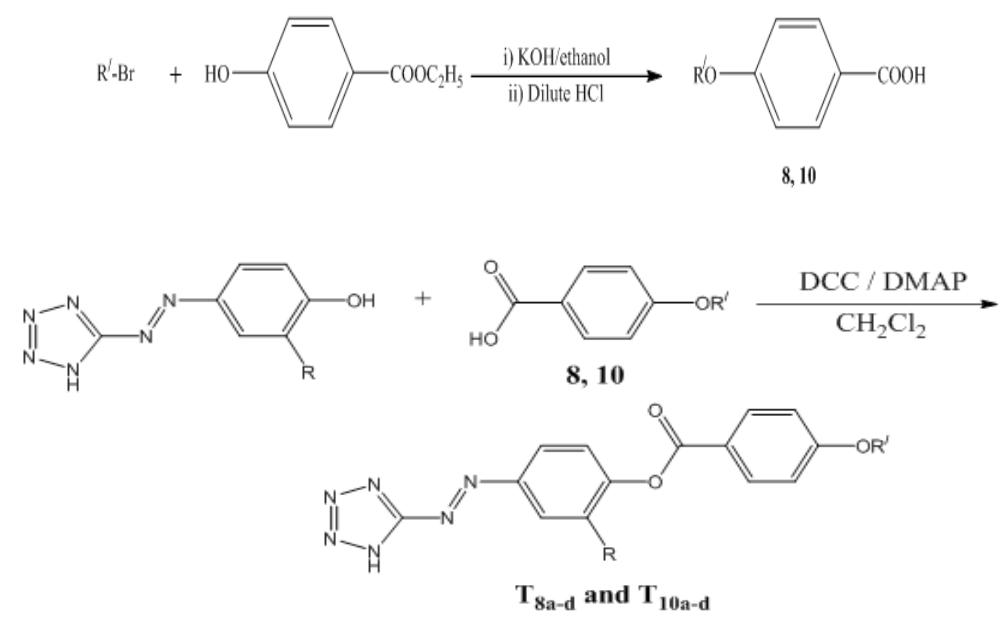

\begin{tabular}{cccl}
\hline Compound & $\mathbf{R}$ & $\mathbf{R}^{\prime}$ & Name \\
\hline $\mathrm{T}_{8 \mathrm{a}}$ & $\mathrm{H}$ & $\mathrm{C}_{8} \mathrm{H}_{17} \mathrm{O}-$ & 4-((1H-tetrazol-5-yl)diazenyl)phenyl 4-(octyloxy)benzoate \\
$\mathrm{T}_{8 \mathrm{~b}}$ & $\mathrm{Me}$ & $\mathrm{C}_{8} \mathrm{H}_{17} \mathrm{O}-$ & 4-((1H-tetrazol-5-yl)diazenyl)-2-methylphenyl-4-(octyloxy)benzoate \\
$\mathrm{T}_{8 \mathrm{c}}$ & $\mathrm{C}_{2} \mathrm{H}_{5}$ & $\mathrm{C}_{8} \mathrm{H}_{17} \mathrm{O}-$ & 4-((1H-tetrazol-5-yl)diazenyl)-2-ethylphenyl-4-(octyloxy)benzoate \\
$\mathrm{T}_{8 \mathrm{~d}}$ & Tert-butyl & $\mathrm{C}_{8} \mathrm{H}_{17} \mathrm{O}-$ & 4-((1H-tetrazol-5-yl)diazenyl)-2-(tert-butyl)phenyl-4-(octyloxy)benzoate \\
$\mathrm{T}_{10 \mathrm{a}}$ & $\mathrm{H}$ & $\mathrm{C}_{10} \mathrm{H}_{21} \mathrm{O}-$ & (4-((1H-tetrazol-5-yl)diazenyl)phenyl-4-(decyloxy)benzoate \\
$\mathrm{T}_{10 \mathrm{~b}}$ & $\mathrm{Me}$ & $\mathrm{C}_{10} \mathrm{H}_{21} \mathrm{O}-$ & 4-((1H-tetrazol-5-yl)diazenyl)-2-methylphenyl-4-(decyloxy)benzoate \\
$\mathrm{T}_{10 \mathrm{c}}$ & $\mathrm{C}_{2} \mathrm{H}_{5}$ & $\mathrm{C}_{10} \mathrm{H}_{21} \mathrm{O}-$ & 4-((1H-tetrazol-5-yl)diazenyl)-2-ethylphenyl-4-(decyloxy)benzoate \\
$\mathrm{T}_{10 \mathrm{~d}}$ & Tert-butyl & $\mathrm{C}_{10} \mathrm{H}_{21} \mathrm{O}-$ & 4-((1H-tetrazol-5-yl)diazenyl)-2-(tert-butyl)phenyl-4-(decyloxy)benzoate \\
\hline
\end{tabular}

TABLE 1. Elemental analysis of compounds $\left(T_{a-d}, T_{8 a, b}\right.$ and $\left.T_{10 c, d}\right)$

\begin{tabular}{|c|c|c|c|c|c|c|c|c|}
\hline \multirow[b]{2}{*}{ Cpd. } & \multirow[b]{2}{*}{ M Formula } & \multirow[b]{2}{*}{ M. P. ${ }^{\circ} \mathbf{C}$} & \multicolumn{6}{|c|}{ Analysis calculations } \\
\hline & & & \multicolumn{2}{|c|}{$\mathrm{C} \%$} & \multicolumn{2}{|c|}{$\mathrm{H} \%$} & \multicolumn{2}{|c|}{ N\% } \\
\hline $\mathrm{T}_{\mathrm{a}}$ & $\mathrm{C}_{7} \mathrm{H}_{7} \mathrm{~N}_{6} \mathrm{O}$ & $136-38$ & $\begin{array}{l}\text { Calc. } \\
44.21\end{array}$ & $\begin{array}{c}\text { Obs. } \\
44.58\end{array}$ & $\begin{array}{r}\text { Calc. } \\
3.18\end{array}$ & $\begin{array}{l}\text { Obs. } \\
3.06\end{array}$ & $\begin{array}{l}\text { Clac. } \\
44.19\end{array}$ & $\begin{array}{c}\text { Obs. } \\
43.94\end{array}$ \\
\hline $\mathrm{T}_{\mathrm{b}}$ & $\mathrm{C}_{8} \mathrm{H}_{8} \mathrm{~N}_{6} \mathrm{O}$ & $128-30$ & 47.06 & 46.95 & 3.95 & 4.08 & 41.16 & 41.14 \\
\hline $\mathrm{T}_{\mathrm{c}}$ & $\mathrm{C}_{9} \mathrm{H}_{10} \mathrm{~N}_{6} \mathrm{O}$ & $124-25$ & 49.54 & 48.99 & 4.62 & 4.78 & 38.51 & 38.9 \\
\hline $\mathrm{T}_{\mathrm{d}}$ & $\mathrm{C}_{11} \mathrm{H}_{14} \mathrm{~N}_{6} \mathrm{O}$ & $80-82$ & 53.65 & 53.38 & 5.73 & 6.02 & 34.13 & 34.11 \\
\hline $\mathrm{T}_{8 \mathrm{a}}$ & $\mathrm{C}_{22} \mathrm{H}_{26} \mathrm{~N}_{6} \mathrm{O}_{3}$ & $235-36$ & 62.54 & 63.01 & 6.20 & 6.04 & 19.89 & 19.58 \\
\hline $\mathrm{T}_{8 \mathrm{~b}}$ & $\mathrm{C}_{23} \mathrm{H}_{28} \mathrm{~N}_{6} \mathrm{O}_{3}$ & $238-40$ & 63.29 & 62.99 & 6.47 & 6.58 & 19.25 & 19.44 \\
\hline $\mathrm{T}_{8 \mathrm{c}}$ & $\mathrm{C}_{24} \mathrm{H}_{30} \mathrm{~N}_{6} \mathrm{O}_{3}$ & $208-10$ & 63.98 & 64.21 & 6.71 & 6.68 & 18.65 & 18.45 \\
\hline $\mathrm{T}_{8 \mathrm{~d}}$ & $\mathrm{C}_{26} \mathrm{H}_{34} \mathrm{~N}_{6} \mathrm{O}_{3}$ & $165-67$ & 65.25 & 65.85 & 7.16 & 6.89 & 17.56 & 17.23 \\
\hline $\mathrm{T}_{10 \mathrm{a}}$ & $\mathrm{C}_{25} \mathrm{H}_{32} \mathrm{~N}_{6} \mathrm{O}_{3}$ & $224-25$ & 63.98 & 64.24 & 6.71 & 6.43 & 18.65 & 18.67 \\
\hline $\mathrm{T}_{10 \mathrm{~b}}$ & $\mathrm{C}_{24} \mathrm{H}_{30} \mathrm{~N}_{6} \mathrm{O}_{3}$ & $227-30$ & 64.64 & 63.94 & 6.94 & 7.04 & 18.09 & 18.69 \\
\hline $\mathrm{T}_{10 \mathrm{c}}$ & $\mathrm{C}_{26} \mathrm{H}_{34} \mathrm{~N}_{6} \mathrm{O}_{3}$ & $189-90$ & 65.25 & 65.87 & 7.16 & 6.94 & 17.56 & 17.16 \\
\hline $\mathrm{T}_{10 \mathrm{~d}}$ & $\mathrm{C}_{28} \mathrm{H}_{38} \mathrm{~N}_{6} \mathrm{O}_{3}$ & $158-60$ & 66.38 & 66.76 & 7.56 & 6.55 & 16.59 & 17.22 \\
\hline
\end{tabular}

The data obtained in Table 1 reveals that the experimental results were in good agreement with the calculated values. Infra-Red spectral bands of compounds $\mathrm{T}_{\mathrm{a}-\mathrm{d}}, \mathrm{T}_{8 \mathrm{a}-\mathrm{d}}$ and $\mathrm{T}_{10 \mathrm{a}-\mathrm{d}}$ Infra-Red spectrum of $\mathrm{T}_{\mathrm{a}-\mathrm{d}}$ 
TABLE 2. Characteristic infrared bands for $T_{a-d}$

\begin{tabular}{cccccccc}
\hline & & & \multicolumn{5}{c}{$\mathrm{n} \mathrm{Cm}^{-1}$} \\
$\mathrm{Cpd}$. & $\mathrm{R}$ & $\mathrm{OH}$ & $\mathrm{NH}$ & $\mathrm{CH}_{\text {Aromatic }}$ & $\mathrm{CH}_{\text {Aliphatic }}$ & $\mathrm{N}=\mathrm{N}$ & $\mathrm{C}=\mathrm{C}$ \\
\hline $\mathrm{T}_{\mathrm{a}}$ & $\mathrm{H}$ & 3504 & 3356 & 3098 & - & 1472 & 1586 \\
$\mathrm{~T}_{\mathrm{b}}$ & $-\mathrm{CH}_{3}$ & 3546 & 3379 & 3195 & 2973 & 1463 & 1597 \\
$\mathrm{~T}_{\mathrm{c}}$ & $-\mathrm{C} 2 \mathrm{H} 5$ & 3493 & 3389 & 3130 & 2971 & 1455 & 1597 \\
$\mathrm{~T}_{\mathrm{d}}$ & t-But. & 3514 & 3389 & 3164 & 2957 & 1483 & 1591 \\
\hline
\end{tabular}

Data obtained in Table 2 illustrate the following:

- The $-\mathrm{OH}$ bands of the four compounds appear at $\left(3546-3504 \mathrm{~cm}^{-1}\right)$, whereas the $-\mathrm{NH}$ streatching bands appear at $\left(3356-3389 \mathrm{~cm}^{-1}\right)$.

- The azo group $(\mathrm{N}=\mathrm{N})$ for the prepared compounds has the values of $\left(1463-1483 \mathrm{~cm}^{-1}\right)$.

- The values of $-\mathrm{CH}$ aromatic and $-\mathrm{CH}$ aliphatic agree with the theoretical ones.

TABLE 3. Characteristic infrared bands for $T_{8 \mathrm{a}-\mathrm{d}}$ and $T_{10 \mathrm{a}-\mathrm{d}}$

\begin{tabular}{|c|c|c|c|c|c|c|c|c|c|}
\hline Cpd. & $\mathrm{R}$ & $\mathrm{R}^{\prime}$ & $\mathrm{NH}$ & $\mathrm{C}=\mathrm{O}$ & $\mathrm{CH}_{\text {Aromatic }}$ & $\begin{array}{l}\mathrm{V} \mathrm{Cm}^{-1} \\
\mathrm{CH}\end{array}$ & $\mathrm{N}=\mathrm{N}$ & $\mathrm{C}-\mathrm{O}-\mathrm{C}$ & $\mathrm{C}=\mathrm{C}$ \\
\hline $\mathrm{T}_{8 \mathrm{a}}$ & $\mathrm{H}$ & $-\mathrm{OC}_{8} \mathrm{H}_{17}$ & 3326 & 1773 & 3181 & 2931 & 1472 & 1245 & 1586 \\
\hline $\mathrm{T}_{8 \mathrm{~b}}^{8 \mathrm{a}}$ & $-\mathrm{CH}_{3}$ & $-\mathrm{OC}_{8}^{8} \mathrm{H}_{17}$ & 3328 & 1774 & 3182 & 2929 & 1463 & 1244 & 1597 \\
\hline $\mathrm{T}_{8 \mathrm{c}}^{8 \mathrm{c}}$ & $-\mathrm{C} 2 \mathrm{H} 5$ & $-\mathrm{OC}_{8}^{8} \mathrm{H}_{17}$ & 3356 & 1769 & 3178 & 2932 & 1465 & 1250 & 1588 \\
\hline $\mathrm{T}_{8 \mathrm{~d}}^{8 \mathrm{c}}$ & t-But. & $-\mathrm{OC}_{8}^{8} \mathrm{H}_{17}^{11}$ & 3342 & 1771 & 3156 & 2928 & 1464 & 1251 & $\begin{array}{l}1592 \\
1506\end{array}$ \\
\hline$T^{10 a}$ & $\stackrel{\mathrm{H}}{\mathrm{CH}}$ & $\begin{array}{l}-\mathrm{OC}^{10} \mathrm{H}^{\prime} \\
-\mathrm{OC}^{10} \mathrm{H}^{21}\end{array}$ & $\begin{array}{l}3348 \\
3358\end{array}$ & $\begin{array}{l}1734 \\
1746\end{array}$ & $\begin{array}{l}3118 \\
3125\end{array}$ & $\begin{array}{l}2929 \\
2933\end{array}$ & $\begin{array}{l}1472 \\
1465\end{array}$ & $\begin{array}{l}1247 \\
1248\end{array}$ & $\begin{array}{l}1596 \\
1591\end{array}$ \\
\hline $\mathrm{T}_{10 \mathrm{c}}^{10 \mathrm{~b}}$ & $-\mathrm{C}^{2} \mathrm{H}^{3} 5$ & $-\mathrm{OC}_{10}^{10} \mathrm{H}_{21}^{21}$ & 3326 & 1728 & 3117 & 2930 & 1474 & 1252 & 1597 \\
\hline $\mathrm{T}_{10 \mathrm{~d}}$ & t-But. & $-\mathrm{OC}_{10} \mathrm{H}_{21}$ & 3332 & 1745 & 3123 & 2927 & 1483 & 1244 & 1591 \\
\hline
\end{tabular}

Infra-Red spectrum of $T_{8 a-d}$ and $T_{10 a-d}$

The infra-red absorption bands for compounds $\mathrm{T}_{8 \mathrm{a}-\mathrm{d}}$ and $\mathrm{T}_{10 \mathrm{a}-\mathrm{d}}$, (Table 3), explain the following:

- The -NH streatching bands appear at $\left(3326-3358 \mathrm{~cm}^{-1}\right)$, whereas the -OH bands disappear (after estrification).

- The carbonyl ester streatching bands appear within the expected ranges $\left(1728-1773 \mathrm{~cm}^{-1}\right)$. This is due to the $\pi$ bond character of the carbonyl group (Fig. 3).

- The C-O-C groups have the values ranged from $1244 \mathrm{~cm}^{-1}$ to $1252 \mathrm{~cm}^{-1}$.

- The other absorption bands of the eight compounds are reasonable in their values.

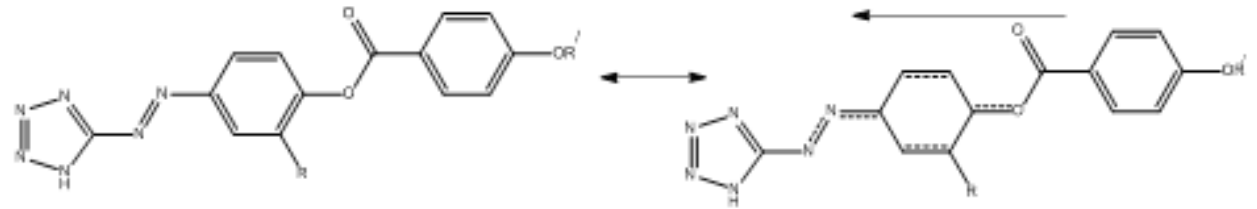

Fig 3. Resonating structure of compounds $T_{8 \mathrm{a}-\mathrm{d}}$ and $T_{10 \mathrm{a}-\mathrm{d}}$

\section{${ }^{1} H-N M R$}

Nuclear Magnetic Resonance of compounds $T_{a-d}$

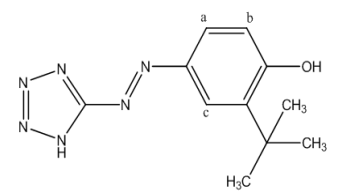<smiles>CCc1cc(N=Nc2nnn[nH]2)ccc1O</smiles>

$\mathrm{T}_{\mathrm{b}}$

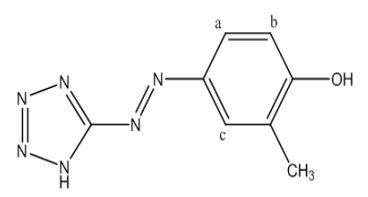

$\mathrm{T}_{\mathrm{c}}$

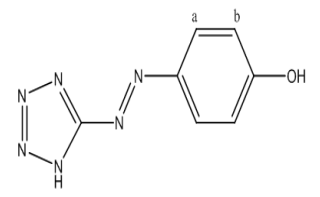

$\mathrm{T}_{\mathrm{d}}$

Egypt. J. Chem. 61, No. 1 (2018) 
TABLE 4. Chemical Shifts (d) of compounds $T_{a-d}$

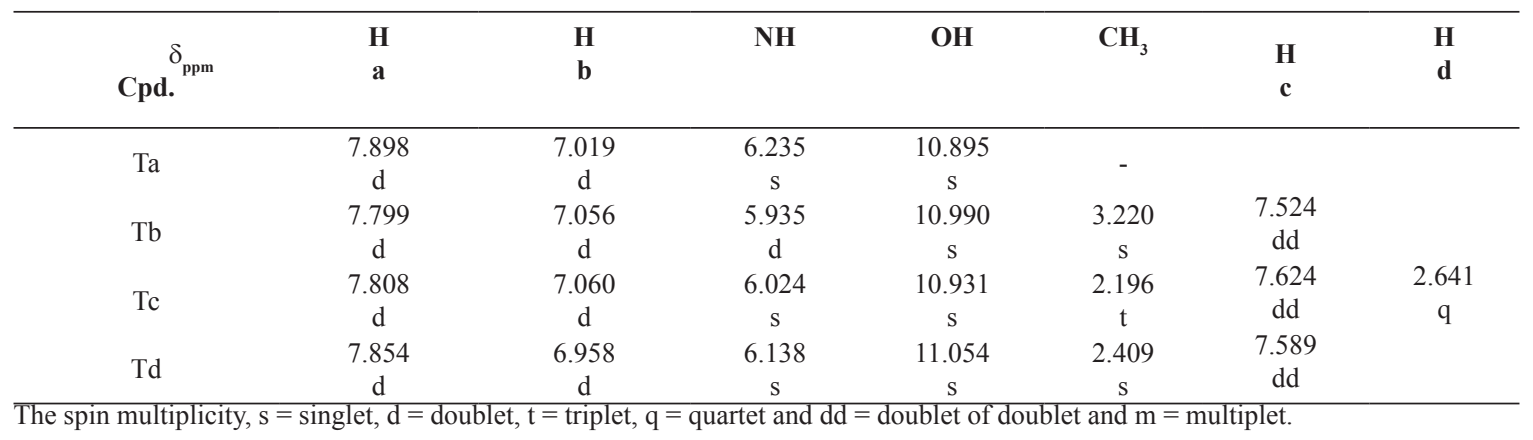

\section{Antimicrobial Activity}

The antimicrobial activity of the newly synthesized compounds was screened for their antibacterial and antifungal activities using agar well diffusion method [26]. Mean zone of inhibition in $\mathrm{mm}$ beyond well diameter (6 $\mathrm{mm}$ ) produced on a range of pathogenic microorganisms, using DMSO as solvent control, (The regional center of Mycology and Biotechnology, antimicrobial activity unit, AlAzhar University). The test was done using the diffusion agar technique, Well Diameter: $6.0 \mathrm{~mm}$ (100 mL was tested), RCMB. The sample was tested at $5 \mathrm{mg} / \mathrm{ml}$ concentration.

\section{Results and Discussion}

Elucidation of structures of the prepared

Table 4 illustrates the following:

The two aromatic (a) protons, of the benzene ring $\left(\mathrm{T}_{\mathrm{a}}\right)$ are more deshielded than (b) protons, because of the high electronegative tetrazole ring. In case of compounds $\left(\mathrm{T}_{\mathrm{b}-\mathrm{d}}\right)$, the three aromatic protons are not similar in their chemical shifts and the proton (c) appears to have a doublet of doublet splitting.

The nine protons of the tert-butyl group $\left(\mathrm{T}_{\mathrm{d}}\right)$ appear singlet and having the chemical shift value of $2.409 \mathrm{ppm}$ whereas the three protons of the methyl group $\left(\mathrm{T}_{\mathrm{c}}\right)$ have triplet spin multiplicity with $2.196 \mathrm{ppm}$ chemical shift value.

In case of compound $T_{b}$, the methyl protons have the chemical shift value of $3.22 \mathrm{ppm}$ with singlet spin multiplicity.

The proton (c) has the spin multiplicity doublet of doublet, due to the unsymmetrical protons (a and b).
Nuclear Magnetic Resonance of compounds $T_{8 a-d}$ and $T_{10 a-d}$

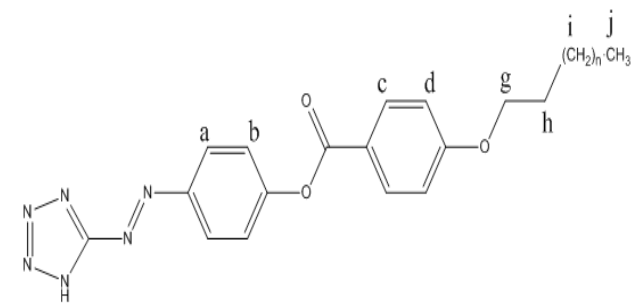

$\mathrm{T}_{8,10 \mathrm{a}}$

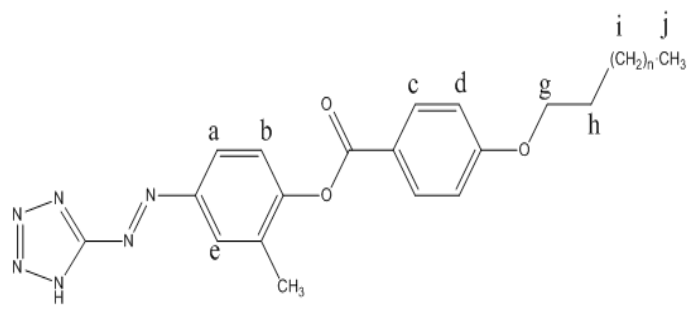

$\mathrm{T}_{8,10 \mathrm{~b}}$

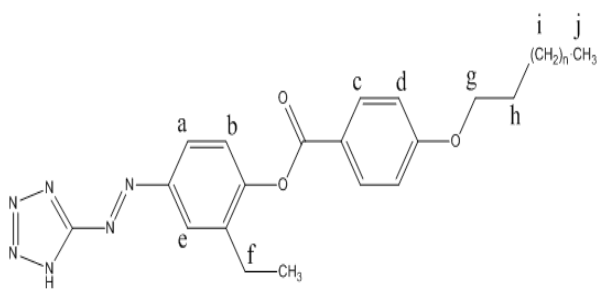

$\mathrm{T}_{8,10 \mathrm{c}}$

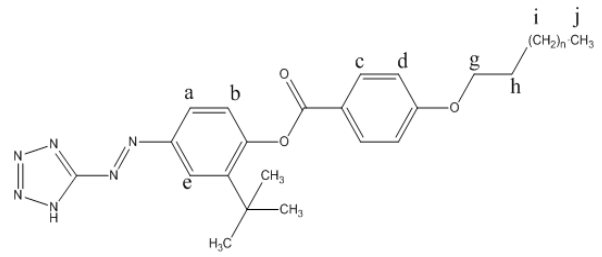

Where $\mathrm{n}_{=} 8$ and 10
$\mathrm{T}_{8,10 \mathrm{~d}}$

Egypt. J. Chem. 61, No.1 (2018) 
TABLE 5. Chemical Shifts (d) of compounds $T_{8 a-d}$ and $T_{10 a-d}$

\begin{tabular}{|c|c|c|c|c|c|c|c|c|c|c|c|c|}
\hline $\begin{array}{l}\mathrm{d}_{\mathrm{ppm}} \\
\text { Cpd. }\end{array}$ & $\begin{array}{c}\mathrm{H} \\
\mathrm{a}\end{array}$ & $\begin{array}{l}\mathrm{H} \\
\mathrm{b}\end{array}$ & $\overline{\mathrm{NH}}$ & $\begin{array}{l}\mathrm{H} \\
\mathrm{c}\end{array}$ & $\mathrm{CH}_{3}$ & $\begin{array}{c}\mathrm{H} \\
\mathrm{d}\end{array}$ & $\begin{array}{c}\mathrm{H} \\
\mathrm{e}\end{array}$ & $\begin{array}{c}\mathrm{H} \\
\mathrm{f}\end{array}$ & $\begin{array}{c}\mathrm{H} \\
\mathrm{g}\end{array}$ & $\begin{array}{l}\mathrm{H} \\
\mathrm{h}\end{array}$ & $\begin{array}{l}\mathrm{H} \\
\mathrm{i}\end{array}$ & $\begin{array}{l}\mathrm{H} \\
\mathrm{j}\end{array}$ \\
\hline $\mathrm{T}_{8 \mathrm{a}}$ & $\begin{array}{c}7.824 \\
\text { d }\end{array}$ & $\begin{array}{c}7.028 \\
d\end{array}$ & $\begin{array}{c}5.573 \\
\mathrm{~s}\end{array}$ & $\begin{array}{c}8.248 \\
d\end{array}$ & - & $\begin{array}{c}6.985 \\
d\end{array}$ & - & - & $\begin{array}{c}3.318 \\
t\end{array}$ & $\begin{array}{c}2.254 \\
\mathrm{~m}\end{array}$ & $\begin{array}{c}1.728 \\
\mathrm{~m}\end{array}$ & $\begin{array}{c}1.135 \\
\mathrm{t}\end{array}$ \\
\hline $\mathrm{T}_{8 \mathrm{~b}}$ & $\begin{array}{c}7.768 \\
d\end{array}$ & $\begin{array}{c}6.994 \\
\mathrm{~d}\end{array}$ & $\begin{array}{c}5.568 \\
\mathrm{~s}\end{array}$ & $\begin{array}{c}8.236 \\
d\end{array}$ & $\begin{array}{c}3.318 \\
3 \mathrm{~s}\end{array}$ & $\begin{array}{c}7.024 \\
\mathrm{~d}\end{array}$ & $\begin{array}{c}7.682 \\
\mathrm{dd}\end{array}$ & - & $\begin{array}{c}3.468 \\
\mathrm{t}\end{array}$ & $\begin{array}{c}2.232 \\
\mathrm{~m}\end{array}$ & $\begin{array}{c}1.684 \\
\mathrm{~m}\end{array}$ & $\begin{array}{c}1.136 \\
\mathrm{t}\end{array}$ \\
\hline $\mathrm{T}_{8 \mathrm{c}}$ & 7.800 & 7.048 & $\begin{array}{c}5.582 \\
\mathrm{~s}\end{array}$ & $\begin{array}{c}8.324 \\
d\end{array}$ & $\begin{array}{c}2.224 \\
3 \mathrm{t}\end{array}$ & $\begin{array}{c}7.004 \\
\mathrm{~d}\end{array}$ & $\begin{array}{c}7.684 \\
\text { dd }\end{array}$ & $\begin{array}{c}3.428 \\
q\end{array}$ & $\begin{array}{c}3.382 \\
\mathrm{t}\end{array}$ & $\begin{array}{c}2.248 \\
\mathrm{~m}\end{array}$ & $\begin{array}{c}1.728 \\
\mathrm{~m}\end{array}$ & $\begin{array}{c}1.048 \\
\mathrm{t}\end{array}$ \\
\hline $\mathrm{T}_{8 \mathrm{~d}}$ & 7.746 & 7.082 & $\begin{array}{c}5.604 \\
\mathrm{~s}\end{array}$ & $\begin{array}{c}8.286 \\
d\end{array}$ & $\begin{array}{c}2.186 \\
9 \mathrm{~s}\end{array}$ & $\begin{array}{c}7.006 \\
d\end{array}$ & $\begin{array}{c}7.721 \\
\mathrm{dd}\end{array}$ & - & $\begin{array}{c}3.368 \\
t\end{array}$ & $\begin{array}{c}2.268 \\
\mathrm{~m}\end{array}$ & $\begin{array}{c}1.778 \\
\mathrm{~m}\end{array}$ & $\begin{array}{c}0.998 \\
\mathrm{t}\end{array}$ \\
\hline $\mathrm{T}_{10 \mathrm{a}}$ & $\begin{array}{c}7.814 \\
\mathrm{~d}\end{array}$ & $\begin{array}{c}7.112 \\
\mathrm{~d}\end{array}$ & $\begin{array}{c}5.582 \\
\mathrm{~s}\end{array}$ & $\begin{array}{c}8.198 \\
d\end{array}$ & - & $\begin{array}{c}6.989 \\
\mathrm{~d}\end{array}$ & - & - & $\begin{array}{c}3.408 \\
\mathrm{t}\end{array}$ & $\begin{array}{c}2.264 \\
\mathrm{~m}\end{array}$ & $\begin{array}{c}1.804 \\
\mathrm{~m}\end{array}$ & $\begin{array}{c}0.986 \\
t\end{array}$ \\
\hline $\mathrm{T}_{10 \mathrm{~b}}$ & $\begin{array}{c}7.772 \\
\mathrm{~d}\end{array}$ & 7.085 & $\begin{array}{c}5.589 \\
\mathrm{~s}\end{array}$ & $\begin{array}{c}8.218 \\
\mathrm{~d}\end{array}$ & $\begin{array}{c}3.426 \\
3 \mathrm{~s}\end{array}$ & $\begin{array}{c}6.978 \\
\mathrm{~d}\end{array}$ & $\begin{array}{c}7.608 \\
\mathrm{dd}\end{array}$ & - & $\begin{array}{c}3.368 \\
t\end{array}$ & $\begin{array}{c}2.246 \\
\mathrm{~m}\end{array}$ & $\begin{array}{c}1.724 \\
\mathrm{~m}\end{array}$ & $\begin{array}{c}1.001 \\
\mathrm{t}\end{array}$ \\
\hline $\mathrm{T}_{10 \mathrm{c}}$ & $\begin{array}{c}7.804 \\
\mathrm{~d}\end{array}$ & $\begin{array}{c}7.056 \\
d\end{array}$ & $\begin{array}{c}5.574 \\
\mathrm{~s}\end{array}$ & $\begin{array}{c}8.186 \\
d\end{array}$ & $\begin{array}{c}2.132 \\
3 \mathrm{t}\end{array}$ & $\begin{array}{c}7.026 \\
\mathrm{~d}\end{array}$ & $\begin{array}{c}7.564 \\
\mathrm{dd}\end{array}$ & $\begin{array}{c}3.321 \\
q\end{array}$ & $\begin{array}{c}3.568 \\
t\end{array}$ & $\begin{array}{c}2.245 \\
\mathrm{~m}\end{array}$ & $\begin{array}{c}1.701 \\
\mathrm{~m}\end{array}$ & $\begin{array}{c}1.135 \\
\mathrm{t}\end{array}$ \\
\hline $\mathrm{T}_{10 \mathrm{~d}}$ & $\begin{array}{c}7.689 \\
\mathrm{~d}\end{array}$ & $\begin{array}{c}7.068 \\
d\end{array}$ & $\begin{array}{c}5.591 \\
\mathrm{~S}\end{array}$ & $\begin{array}{c}8.195 \\
d\end{array}$ & $\begin{array}{c}2.229 \\
9 \mathrm{~s}\end{array}$ & $\begin{array}{c}6.904 \\
\mathrm{~d}\end{array}$ & $\begin{array}{c}7.486 \\
\mathrm{dd}\end{array}$ & & $\begin{array}{c}3.323 \\
\mathrm{t}\end{array}$ & $\begin{array}{c}2.222 \\
\mathrm{~m}\end{array}$ & $\begin{array}{c}1.619 \\
\mathrm{~m}\end{array}$ & $\begin{array}{c}1.260 \\
\mathrm{t}\end{array}$ \\
\hline
\end{tabular}

From Table 5 the above data are explained as follows:

The peaks related to the (OH-) proton disappeared which confirm the formation of esters for compounds $\mathrm{T}_{8 \mathrm{a}-\mathrm{d}}$ and $\mathrm{T}_{10 \mathrm{a}-\mathrm{d}}$.

The highly deshielded aromatic proton (a) has the values of (7.689 to $7.824 \mathrm{ppm}$ ) for the eight compounds.

Proton of the type (e) has the values ranged from (7.486 to $7.682 \mathrm{ppm}$ ) with spin multiplicity doublet of doublet (affected by the unsymmetrical protons ( $\mathrm{a}$ and $\mathrm{b}$ ) for compounds $\mathrm{T}_{8 \mathrm{~b}-\mathrm{d}}$ and $\mathrm{T}_{10 \mathrm{~b}-\mathrm{d}}$

The $\mathrm{CH}_{3}$ protons for compounds $\mathrm{T}_{8 \mathrm{~b}}$ and $\mathrm{T}_{10 \mathrm{~b}}$ appear singlet with chemical shift values of 3.318 and 3.426 respectively, whereas the $\mathrm{CH}_{3}$ protons for compounds $\mathrm{T}_{8 \mathrm{c}}$ and $\mathrm{T}_{10 \mathrm{c}}$ appear triplet with chemical shift values of 2.224 and 2.132 ppm respectively. Consequently the $\mathrm{CH}_{3}$ protons (9 protons) for compounds $\mathrm{T}_{8 \mathrm{~d}}$ and $\mathrm{T}_{10 \mathrm{~d}}$ appear singlet with chemical shift values of 2.186 and $2.229 \mathrm{ppm}$ respectively.

The proton of type (f), for compounds $\mathrm{T}_{8 \mathrm{c}}$ and $\mathrm{T}_{10 \mathrm{c}}$, appear quartet with chemical shift values of 3.428 and $3.321 \mathrm{ppm}$ respectively.

\section{Antimicrobial Activity}

The pilot study of the antimicrobial Activity for the synthesized azo tetrazole derivatives are illustrated in the following tables.

Egypt. J. Chem. 61, No. 1 (2018)
Antimicrobial Activity of $T_{a-d}$ :

From data obtained in Tables 6 and 7 the antimicrobial work (as a pilot study) illustrates that Compounds $\mathrm{T}_{\mathrm{a}-\mathrm{d}}, \mathrm{T}_{8 \mathrm{a}-\mathrm{d}}$ and $\mathrm{T}_{10 \mathrm{a}-\mathrm{d}}$ show negative antimicrobial activity versus fungi such as Aspergillus fumigatus, and Candida albicans.

Table 6 explains that, with respect to the effect of Gentamycin on Gram positive bacteria (Staphylococcus aureus and Bacillus Subtilis), and Gram negative bacteria (Salmonella typhimurium and Escherichia coli) the efficiency of $\mathrm{T}_{\mathrm{a}-\mathrm{d}}$ behaves as follows:

In case of Gram Positive bacteria (Staphylococcus aureus), the effeciency shows $50 \%, 54.16 \%, 45.83 \%$ and $66.67 \%$ for the four respective $T_{a}, T_{b}, T_{c}$, and $T_{d}$. However, the efficiency of them on Gram positive bacteria (Bacillus subtilis) shows 42.31\%, 46.15\%, $57.69 \%$, and $69.23 \%$ respectively.

The effect of $\mathrm{T}_{\mathrm{a}}, \mathrm{T}_{\mathrm{b}}, \mathrm{T}_{c}$, and $\mathrm{T}_{\mathrm{d}}$ on Gram negative bacteria (Salmonella typhimurium) get the values of $82.35 \%, 88.23 \%, 70.59 \%$ and $111.76 \%$ (great effect), respectively. In a contrary, in case of Gram negative bacteria (Escherichia coli), the efficiency get the following values: $43.33 \%, 36.66,40 \%$, and $50 \%$ for the four respective compounds $\mathrm{T}_{\mathrm{a}-\mathrm{d}}$.

As illustrated in Table 7, the efficiency of $\mathrm{T}_{8 \mathrm{a}-\mathrm{d}}$ and $\mathrm{T}_{10 \mathrm{a}-\mathrm{d}}$ on Gram positive bacteria (Staphylococcus aureus and Bacillus subtilis) and Gram negative bacteria (Salmonella typhimurium 
and Escherichia coli), with respect to the reference one (Gentamycin), is shown as follows:

Compounds $\mathrm{T}_{8 \mathrm{c}}$ and $\mathrm{T}_{10 \mathrm{c}}$ have no effect on any of the two types of bacteria.

The effect of $\left(\mathrm{T}_{8 \mathrm{a}, \mathrm{b}, \mathrm{d}}\right.$ and $\left.\mathrm{T}_{10 \mathrm{a}, \mathrm{b}, \mathrm{d}}\right)$ on Gram positive bacteria (Staphylococcus aureus), give the respective values: $37.5 \%, 41.66 \%, 37.5 \%$, $41.66 \%, 50 \%$ and $58.33 \%$. While in case of Gram Positive bacteria (Bacillus subtilis), the effective values of the above six compounds are: $30.77 \%$, $42.31 \%, 42.31 \%, 42.31 \%, 50 \%$ and $61.54 \%$ respectively.

The sequential effective values for $\left(\mathrm{T}_{8 \mathrm{a}, \mathrm{b}, \mathrm{d}}\right.$ and $\mathrm{T}_{10 \mathrm{a}, \mathrm{b}, \mathrm{d}}$ ) on Gram negative bacteria (Salmonella typhimurium) are as follows: $52.94 \%, 70.59 \%$, $58.82 \%, 70.59 \%, 76.47 \%$ and $88.23 \%$. Whereas, the effect of them on Gram negative bacteria (Escherichia coli) shows the following values:
$33.33 \%, 36.67 \%, 40 \%, 46.67 \%, 50 \%$ and $66.67 \%$ respectively.

\section{Conclusion}

The structures of the prepared compounds are elucidated using the conventional tools of analysis, (Elemental Analysis, FT-IR and ${ }^{1} \mathrm{H}-\mathrm{NMR}$ spectroscopy).

The net result of using synthesized compounds versus microorganisms, (Gram +ve bacteria and Gram -ve bacteria) showed high antimicrobial activity.

Instead of the three compounds $\mathrm{T}_{\mathrm{a}-\mathrm{c}}, \mathrm{T}_{\mathrm{d}}$ gave higher antimicrobial action for both the two types of bacteria (Gram +ve and Gram-ve), Table (6).

In case of the eight compounds $\left(\mathrm{T}_{8 \mathrm{a}-\mathrm{d}}\right.$ and $\mathrm{T}_{10 \mathrm{a}-\mathrm{d}}$ ), Table (7), $\mathrm{T}_{8 \mathrm{~d}}$ and $\mathrm{T}_{10 \mathrm{~d}}$ gave higher activity for both Gram +ve and Gram -ve bacteria than

TABLE 6. Antimicrobial activity of $T_{a-d}$ on fungi and bacteria

\begin{tabular}{lccccc}
\hline $\begin{array}{l}\text { Sample code } \\
\text { Tested microorganism }\end{array}$ & $\mathbf{T}_{\mathbf{a}}$ & $\mathbf{T}_{\mathbf{b}}$ & $\mathbf{T}_{\mathbf{c}}$ & $\mathbf{T}_{\mathbf{d}}$ & Control \\
\hline $\begin{array}{l}\text { Fungi } \\
\text { Aspergillus fumigatus (RCMB002008) }\end{array}$ & NA & NA & NA & NA & Ketoconazol \\
Candida albicans (RCMB005003) (1) ATCC 10231 & NA & NA & NA & NA & 20 \\
Gram Positive Bacteria & & & & & Gentamycin \\
Staphylococcus aureus (RCMB 010010) & 12 & 13 & 11 & 16 & 24 \\
Bacillus subtillis RCMB 015 (1) NRRL B-543 & 11 & 12 & 15 & 18 & 26 \\
Gram Negative Bacteria & & & & & Gentamycin \\
Salmonella typhimurium RCMB 006 (1) ATCC 14028 & 14 & 15 & 12 & 19 & 17 \\
Escherichia coli (RCMB 010052) ATCC 25955 & 13 & 11 & 12 & 15 & 30 \\
\hline
\end{tabular}

Antimicrobial Activity of T8a-d and T8a-d

TABLE 7. Antimicrobial activity of $T_{8 \mathrm{a}-\mathrm{d}}$ and $T_{10 \mathrm{a}-\mathrm{d}}$ on fungi and bacteria

\begin{tabular}{|c|c|c|c|c|c|c|c|c|c|}
\hline $\begin{array}{l}\text { Sample code } \\
\text { Tested microorganism } \\
\text { Fungi }\end{array}$ & $\mathbf{T}_{8 \mathrm{a}}$ & $\mathbf{T}_{8 \mathrm{~b}}$ & $\mathbf{T}_{8 \mathrm{c}}$ & $\mathbf{T}_{8 \mathrm{~d}}$ & $\mathrm{~T}_{10 \mathrm{a}}$ & $\mathbf{T}_{10 \mathrm{~b}}$ & $\mathbf{T}_{10 \mathrm{c}}$ & $T_{10 d}$ & $\begin{array}{c}\text { Control } \\
\text { Ketoconazol }\end{array}$ \\
\hline $\begin{array}{l}\text { Aspergillus fumigatus (RCMB } \\
002008 \text { ) }\end{array}$ & NA & NA & NA & NA & NA & NA & NA & NA & 17 \\
\hline $\begin{array}{l}\text { Candida albicans (RCMB } \\
\text { 005003) (1) ATCC } 10231\end{array}$ & NA & NA & NA & NA & NA & NA & NA & NA & 20 \\
\hline Gram Positive Bacteria & & & & & & & & & Gentamycin \\
\hline $\begin{array}{l}\text { Staphylococcus aureus (RCMB } \\
010010 \text { ) }\end{array}$ & 9 & 10 & NA & 9 & 10 & 12 & NA & 14 & 24 \\
\hline $\begin{array}{l}\text { Bacillus subtillis RCMB } 015 \text { (1) } \\
\text { NRRL B-543 }\end{array}$ & 8 & 11 & NA & 11 & 11 & 13 & NA & 16 & 26 \\
\hline Gram Negative Bacteria & & & & & & & & & Gentamycin \\
\hline $\begin{array}{l}\text { Salmonella typhimurium RCMB } \\
006 \text { (1) ATCC } 14028\end{array}$ & 9 & 12 & NA & 10 & 12 & 13 & NA & 15 & 17 \\
\hline $\begin{array}{l}\text { Escherichia coli (RCMB } \\
\text { 010052) ATCC } 25955\end{array}$ & 10 & 11 & NA & 12 & 14 & 15 & NA & 20 & 30 \\
\hline
\end{tabular}




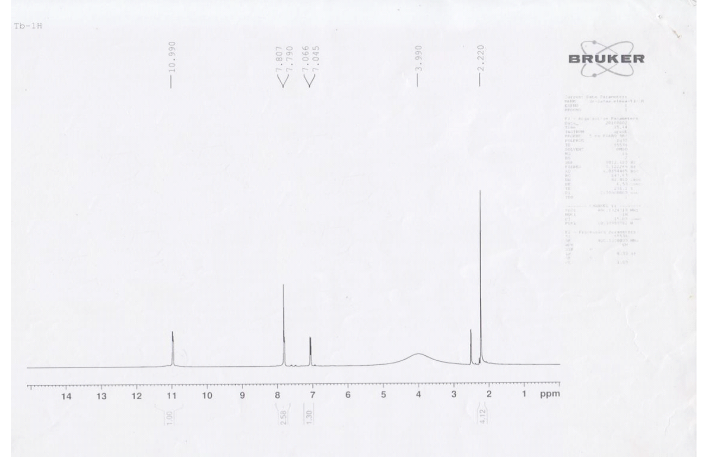

Fig. 3: ${ }^{1} \mathrm{H}-\mathrm{NMR}$ Spectra of $\mathrm{T}_{\mathrm{a}}$

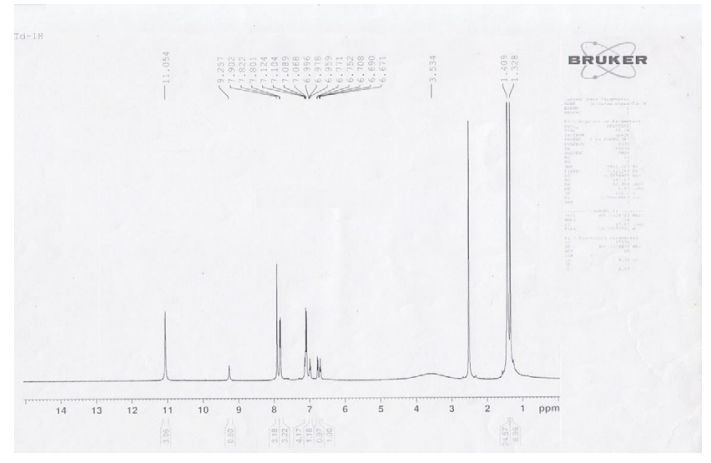

Fig. 5: ${ }^{1} \mathrm{H}-\mathrm{NMR}$ Spectra of $\mathrm{T}_{\mathrm{c}}$

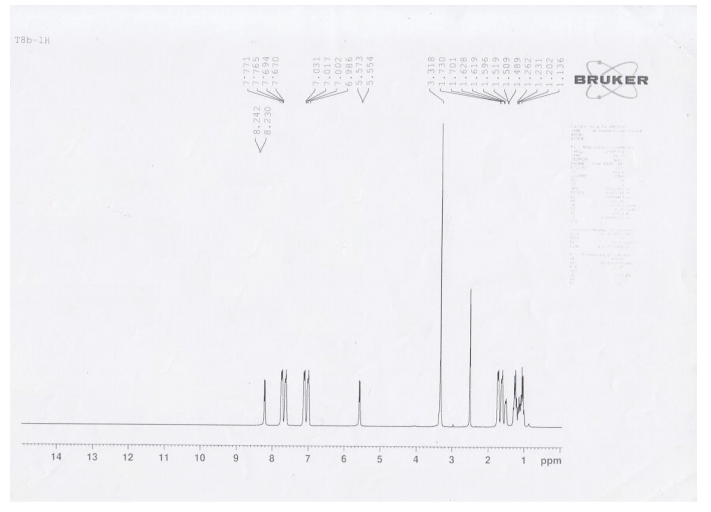

Fig. 7: ${ }^{1} \mathrm{H}-\mathrm{NMR}$ Spectra of $\mathrm{T}_{8 \mathrm{a}}$

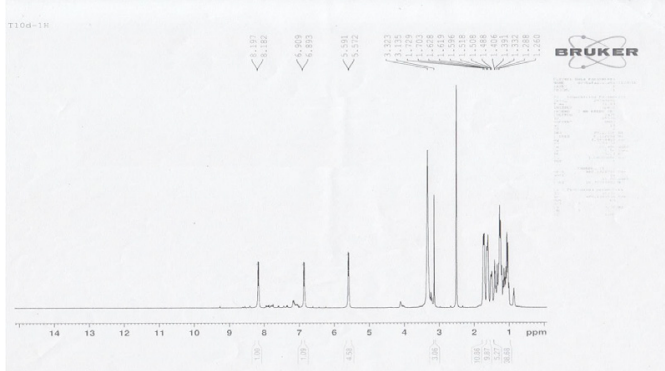

Fig. 9: ${ }^{1} \mathrm{H}-\mathrm{NMR}$ Spectra of $\mathrm{T}_{10 \mathrm{c}}$

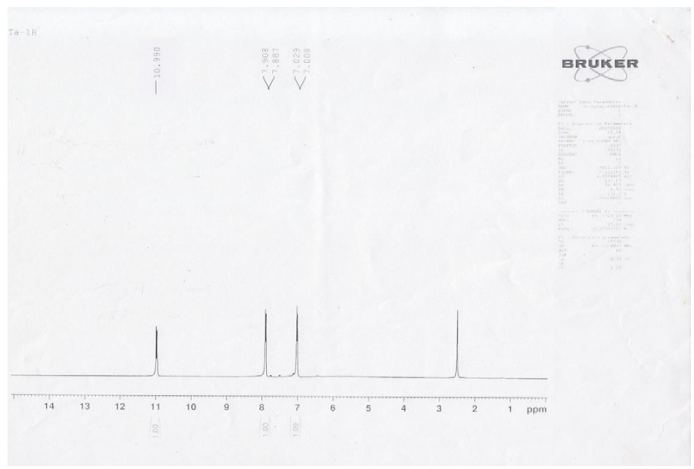

Fig. 4: ${ }^{1} \mathrm{H}-\mathrm{NMR}$ Spectra of $\mathrm{T}_{\mathrm{b}}$

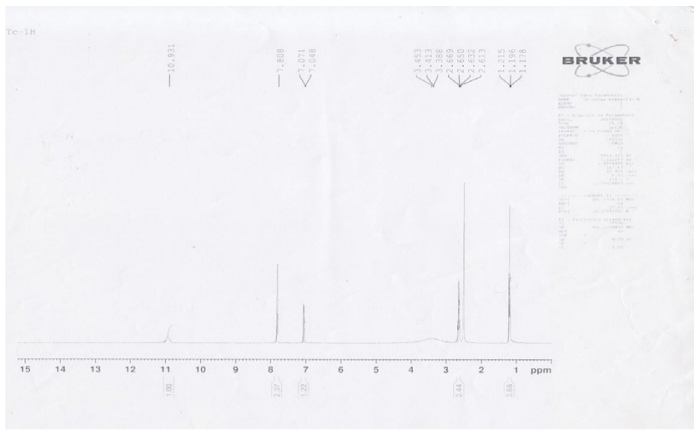

Fig. 6: ${ }^{1} \mathrm{H}-\mathrm{NMR}$ Spectra of $\mathrm{T}_{\mathrm{d}}$

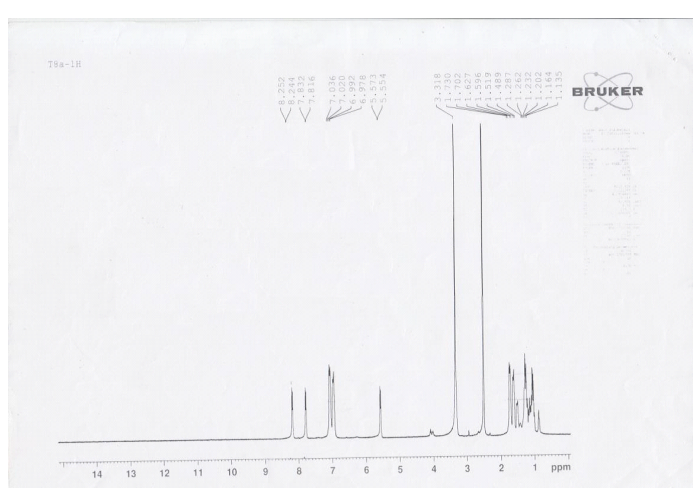

Fig. 8: ${ }^{1} \mathrm{H}-\mathrm{NMR}$ Spectra of $\mathrm{T}_{8 \mathrm{~b}}$

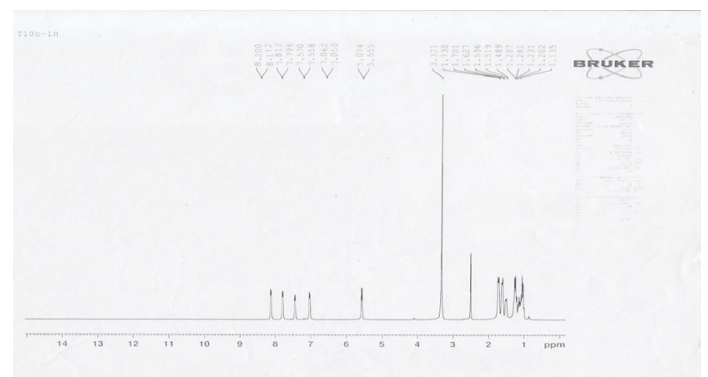

Fig. 10: ${ }^{1} \mathrm{H}-\mathrm{NMR}$ Spectra of $\mathrm{T}_{10 \mathrm{~d}}$ 
the other six compounds

All the twelve prepared compounds have no antifungal activity.

\section{References}

1. R.P. Singh, H. Gao, D.T. Meshri, J.M. Shreeve,"Nitrogen-rich heterocycles" P. Day, X. Duan, T. J. Meyer, G. Parkin, H.W. Roesky, J. P. Sauvage (Eds.), "Structure and Bonding", vol. 125, Springer-Verlag, Berlin, Heidelberg, 35-83 (2007).

2. H. Gao, J. M. Shreeve,; Azole-based energetic salts, Chem. Rev. 111 (11) 7377-7436 (2011)

3. J.A. Joule, K. Mills, "Heterocyclic Chemistry", $4^{\text {th }}$ edition, Blackwell Publishing House, 507-511 (2002).

4. S. Rossi; editor, 2006, Adelide; “Australian Medicines Handbook"; (2006).

5. P. B. Mohite, V. H. Bhaskar; Potential Pharmacological Activities of Tetrazoles in The New Millennium International Journal of Pharm. Tech. Research CODEN (USA): IJPRIF ISSN: 0974-9404 Vol.3, No.3, pp1557-1566 (2011).

6. G. X. Ma, T. L. Zhang, J. G. Zhang, K.B. Yu; Thermal decomposition and molecular structure of 5-aminotetrazolium nitrate. Thermochimica Acta, 423, 137-141 (2004).

7. O. A. Ivashkevich, V. A. Krasitsky, A. I. Lesnikovich, V. M. Astashinsky, E. A. Kostyukevich, B. M. Khusid, V. A. Mansurov; Liquid flame combustion II: Some physical and chemical characteristics of the burning process"Combust. Flame 110, 113 (1997).

8. J. Neutz, O. Grosshardt, S. Schäufele, H. Schuppler, W. Schweikert, "Synthesis, characterization and thermal behavior of guanidinium-5aminotetrazolate (GA) - A New Nitrogen-Rich Compound" Propellants, Explos., Pyrotech. 28, 181-188 (2003).

9. H. Xue, S.W. Arritt, B. Twamley, J.N.M. Shreeve; Energetic Salts from N-Aminoazoles. Inorg. Chem. 43, 7972-7977 (2004).

10. T. M. Klapötke, P. Mayer, A. Schulz, J. J. Weigand; 1,5-Diamino-4-methyltetrazolium Dinitramide.J. Am. Chem. Soc. 127, 2032-2033, (2005).
11. R. A. Parker, T. Kariya, J. M. Grisar and V. Petrow; J. Med. Chern., JO 78, 1 (1977).

12. G. P. Bodey, S. Weaver and T. Pan; A new Penicillin with anti-klebsiella activity: 3-(5-tetrazolyl) penam. J. Antibiot., 30, 724-729 (1977).

13. M. Worsfold, M. J. Marshall and E. B. Ellis; "Enzyme detection using Phenazine Methosulphate and Tetrazolium Salts: Interference by Oxygen” Anal. Biochem., 79, 152-156 (1977).

14. J. Roh, K. Vavrova, A. Hrabalek; "Synthesis and functionalization of 5-Substituted Tetrazoles" Eur. J. Org. Chem., 31, 6101-6118, (2012). (b) C.Biot, H. Bauer, R. H. Schirmer, E. Davioud-Charvet; "5-Substituted tetrazoles as bioisosteres of carboxylic acids. Bioisosterism and mechanistic studies on glutathione reductase inhibitors as antimalarials" J. Med. Chem., 47, 5972-5983 (2004). (c) R. Yella, N. Khatun, S. K. Rout, B. K.Patel; "Tandem regioselective synthesis of tetrazoles and related heterocycles using iodine" Org. Biomol. Chem., 9, 3235-3245 (2011).

15. M. Sathishkumar, P. Shanmugavelan, S. Nagarajan, M. Dinesh, A. Ponnuswamy, "Water promoted one pot three-component synthesis of tetrazoles" New J. Chem., 37, 488-493 (2013). (b) L. V. Myznikov, A. Hrabalek, G. I. Koldobskii; "Drugs in tetrazole series (Review)" Chem. Heterocycl. Compd., 43, 1-9 (2007).

16. S. J. Wittenberger; " Recent developments in tetrazole chemistry. A review" J. Org. Prep. Proced. Int., 26, 499-531 (1994).

17. J.H. Toney, P.M. D. Fitzgerald, N. Grover-Sharma, S.H. Olson, W.J. May, J.G. Sundelof, D.E. Vanderwall, K.A. Cleary, S. K. Grant, J. K. Wu, J. W. Kozarich, D.L. Pompliano, G.G. Hammond; "Antibiotic sensitization using tetrazoles as potent inhibitors of Bactiroids fragilis metallo-blactamase" Chem. Biol., 5, 185-196 (1998). (b) R. E. Ford, P. Knowles, E. Lunt, S. M. Marshall, A. J. Penrose, C. A. Ramsden, A. J. H. Summers, J. L. Walker, D. E. Wright; "Synthesis and quantitative structure-activity relationships of antiallergic 2-hydroxy-N- (1H-tetrazol-5-yl) benzamides and N-(2-hydroxyphenyl)-1H-tetrazole-5carboxamides" J. Med. Chem., 29, 538-549 (1986). (c) N. P. Peet, L. E. Baugh, S. Sundler, J. E. Lewis, E. H.Matthews, E. L.Olberding, D. N. Shah, "3-(1H-Tetrazol-5-yl)-4(3H)-quinazolinone sodium salt (MDL 427): a new antiallergic agent" J. Med. Chem., 29, 2403-2409 (1986).

18. M. S. Poonian, E. F. Nowoswiat, J. F. Blount, M. 
J. Kramer; "Synthesis of tetrazole ribonucleosides and their evaluation as antiviral agents. 2.5-Amino-1-(.beta.-D-ribofuranosyl)- $1 H$ tetrazole and 5-amino-2-(.beta.-ribofuranosyl)2H-tetrazole" J. Med. Chem., 19, $1017-1020$ (1976). (b) E. De Clercq; "Antiviral drugs in current clinical use" J. Clin. Virol., 30, 115133 (2004). (c) L. Navidpour, H. Shadnia, H. Shafaroodi,; M. Amini, A. R. Dehpour, A. Shafiee; "Design, synthesis, and biological evaluation of substituted 2-alkylthio-1,5-diarylimidazoles as selective COX-2 inhibitors" Bioorg. Med. Chem., 15, 1976-1982 (2007). (d) N. Lebouvier, F. Giraud, T. Corbin, Y. M. Na, G. Le Baut, P. Marchand,; M. Le Borgne; "Efficient microwave-assisted synthesis of 1-(1H-indol-1-yl)-2-phenyl-3-(1H1,2,4-triazol-1-yl)propan-2-ols as antifungal agents" Tetrahedron Lett., 47, 6479-6483 (2006).

19. R. Shelkar, A. Singh, J. Nagarkar; "Amberlyst-15 catalyzed synthesis of 5-substituted 1- $H$-tetrazole via $[3+2]$ cycloaddition of nitriles and sodium azide" Tetrahedron Lett., 54, 106-109 (2013) (b) D. Habibi, M. Nasrollahzadeh, A. R. Faraji, Y. Bayat; "Efficient synthesis of arylaminotetrazoles in water" Tetrahedron, 66, 3866-3870 (2010).

20. C. H. Mitch, S. Quimby; J. Int. Patent WO 9851312, (1998).

21. D. Habich; "Synthesis of 3'-(5-Amino-1,2,3,4tetrazol-1-yl)-3'-deoxy-thymidines", Synthesis, 4, 358-360 (1992). (b) L. V. Myznikov, A. Hrabalek, G. I. Koldobskii; "Drugs in the tetrazole series",
Chem. Heterocycl. Compd., 43, 1-9, (2007).

22. Z. H. Abood, R. T. Haiwal, H. T. Ghanim and S. M. Radhi; Synthesis of Some New Schiff Bases, Tetrazole and 1,3-Oxazepine Derivatives Containing Azo Group and 1,3,4-Thiadiazole Moiety, Journal of Babylon University/Pure and Applied Sciences/No.(1)Vol.(21), 2013

23. P.F. Bubnov; Initiating explosives and means of initiation, 311-312 (1940).

24. M.M. Naoum, G. R. Saad, R. I. Nessim, T. A. Abdel-Aziz, and H. Seliger; "Effect of molecular structure on the phase behavior of some liquid crystalline compounds and their binary mixtures II. 4-Hexadecyloxyphenyl arylates and aryl 4-hexadecyloxy benzoates" Liquid Crystals, 23, 789-795, (1997).

25. S.Z. Mohammady, R. I. Nessim, O. R. Shehab and M. M. Naoum; "Effect of steric factors on mesomorphic stability I. 4-(4-Substituted phenylazo)-1-naphthyl 4-alkoxybenzoates" Liquid Crystals, 32, 477-482 (2005).

26. S. M. Morsy, A. M. Badawi, A. Cecchi, A. Scozzafava and C. T. Supuran; "Carbonic anhydrase inhibitors. Biphenylsulfonamides with inhibitory action towards the transmembrane, tumor-associated isozymes IX possess cytotoxic activity against human colon, lung and breast cancer cell lines" J. Enzyme Inhib. Chem., 24(2), 499-505, 2009.

(Received 3/12/2017 accepted 16/1/2018)

\footnotetext{
توليف ودراسة الأنشطة المضادة للميكروبات لبعض المشتقات الجديدة للتثرازول

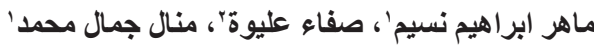

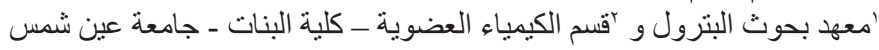

لقد تم تفاعل أربعة (مشتقات الفينول r ) مع H ا -تثيتر ازول_ه-ديازونيوم كلوريد لتخليق أربعة مركبات جديدة

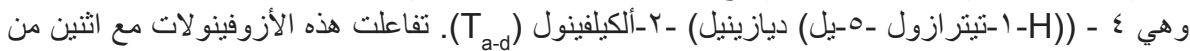

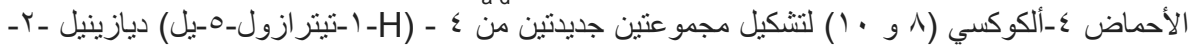

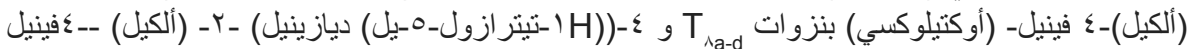

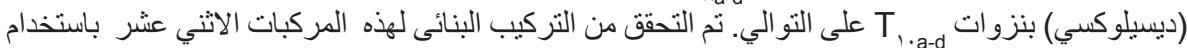

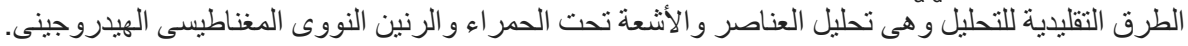

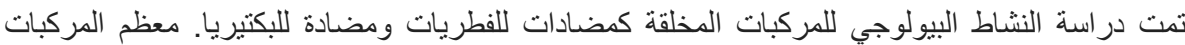

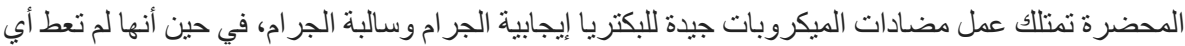
تأثير على الفطريات أمثال (Aspergillus fumigatus) أو (Candida albicans).
} 